\title{
The evaluation of arterial blood pressure in anesthetized dogs with xylazine and ketamine
}

\author{
Buğra Oruç® Serkal Gazyağci® \\ Department of Internal Medicine, Faculty of Veterinary Medicine, University of Kırıkkale, Turkey.
}

\begin{abstract}
Objective: It was aimed to investigate the effects of ketamine combination administered with xylazine used for general anesthesia in dogs on arterial blood pressure, heart rate, and body temperature.

Materials and Methods: In the study, a total of 20 dogs, 14 females and 6 males, from various breeds and ages 1 to 5 , which undergone elective ovariohysterectomy or castration according to body weights. $1 \mathrm{mg} / \mathrm{kg}$ xylazine (xylazine hydrochloride, $23.3 \mathrm{mg} / \mathrm{ml}$, Xylazinbio $2 \%$ Bioveta ${ }^{\circledR}$, Czechia) and $10 \mathrm{mg} / \mathrm{kg}$ ketamine (ketamine hydrochloride, $100 \mathrm{mg} / \mathrm{ml}$, Ketasol 10\% Richter ${ }^{\circledR}$ Pharma Ag, Austria) combination within a single injection with $21 \mathrm{G}$ needle were applied intramuscularly. The food and water access were ceased 12 hours before drug administration. Systolic and diastolic blood pressures, pulse measurements, and body temperatures were measured 3 times before and 5 times during anesthesia (at the 15th, 30th, 45th, 60th and 120th minutes of anesthesia) by using the AM6100 veterinary bedside monitor. Muff was placed to cover $1 / 3$ of the proximal leg and for the artery to be recognizable by the microprocessor. Pulse rates were measured with electrodes connected to the device. Body temperature was measured by a rectal thermometer which was a part of the device. Measurements were taken before anesthesia was considered as control measurements.
\end{abstract}

Results: In systolic blood pressure, the recordings at 0,15 th, 30th mins have been found as statistically significant in relation to 45 th, 60 th, and 120th $(p<0.05)$. In diastolic blood pressure, there were no significant differences recorded. The change between the preintervention and post-application has been found significant $(\mathrm{p}<0.001)$. Body temperature has shown a meaningful change in comparison to the starting point after the readings $(\mathrm{p}<0.001)$.

Conclusion: Eventually, decreases in blood pressure, heartbeat, and body temperature were observed for the dogs that have been anesthetized with the combination of xylazine-ketamine.

Keywords: Blood Pressure, Body Temperature, Diastolic, Dog, Heart Rate, Systolic

\section{INTRODUCTION}

Nowadays, anesthetics are used in immobilization of wild animals, surgical interventions, and during operations for pain relief, as well as during labor, diagnosis, and treatments of diseases with pain (Atasoy and Karadeniz, 2003). After the administration, differences are seen in body temperature, rate of respiration, heart rate, arterial blood pressure, arterial $\mathrm{pH}$, blood gasses, and hematologic values within the organism. (Allen et al., 1986; Hall et al., 2001; Koç and Sarıtaş, 2004).

Xylazine is the first $\alpha 2$ agonist used in veterinary medicine for premedication (Greene and Thurman, 1988; Bilgili and Doğan, 1991). After parental application, while decrease in respiratory rate, bradycardia, hypothermia form is observed, long 
term hypotension forming after intravenous application. (Samy and Othman, 1985; Börkü et al., 2005; Murrel and Hellebrekers, 2005; Lemke, 2007; Cardoso et al., 2014; Kellihan et al., 2015). In some animals, it causes a decrease in intraocular pressure by reducing aqueous humor production (Sinclair, 2003).

Ketamine is a dissociative anesthetic which is a phencyclidine derivative that constitutes dissociation from the surrounding environment like catalepsy (Booth, 1982; Allen et al., 1986; Hellyer, 1996). Depending on the dosage, analgesic, sedative, and anaesthetic effects can be observed (Aantaa and Scheinin, 1993). In recent years, antidepressant-like features were also discovered (Mihara et al., 2012; Franceschelli et al., 2015). When used alongside anaesthetics with depressive effects on the nervous system, hypoxia, hypercarbia and changes in body temperature can occur (Short et al., 1993). It causes increase in heart rate and blood pressure. Temporary respiration depression forms. following anaesthesia, outflow hallucinations may take place. therefore, it is not suggested that it is applied on its own (Colby and Sanford, 1981; Booth, 1982; Haskins et al., 1985; Izci et al., 1993; Gülanber et al., 2001; Topal, 2005; Flecknel, 2016).

The side effects caused by the combination of xylazine-ketamine, which is often used in small animal medicine, are being underestimated. Complications are occurring especially upon usage in animals with an unhealthy cardiovascular system and at absence of essential precautions. In this study, the effect of xylazine-ketamine combination on blood pressure was investigated using the oscillometric technique.

\section{MATERIALS and METHODS}

A variety of dog breeds, 14 females and 6 males, aged between 1-5, weighed $21-45 \mathrm{~kg}$, brought to the clinic for spaying and the method ovariohysterectomy, a castrating method, were used as study subjects. $1 \mathrm{mg} / \mathrm{kg}$ xylazine (xylazine hydrochloride, $23.3 \mathrm{mg} / \mathrm{ml}$, Xylazinbio $2 \%$ Bioveta ${ }^{\circledR}$, Czechia) and $10 \mathrm{mg} / \mathrm{kg}$ ketamine (ketamine hydrochloride, $100 \mathrm{mg} / \mathrm{ml}$, Ketasol 10\% Richter ${ }^{\circledR}$, Pharma Ag, Austria) combination within a single injection with $21 \mathrm{G}$ needle was applied intramuscularly. The food and water access were ceased for 12 hours prior to the practice. Before practice and during the 15th, 30th, 45th, 60th and 120th minutes of the practice their systolic and diastolic blood pressures, pulse rates and body temperatures were recorded, to produce three repeat measures in total. Data recorded before practice was used as control measurements. Measurements were taken by a special veterinary use bed-side monitor (AM6100 Veterinary Monitor, Shanghai-China). Blood pressures were measured automatically by an oscillometer. According to the literature, muff was placed to cover $1 / 3$ of the proximal leg and for the artery to be recognizable by the microprocessor. Pulse rates were measured with electrodes connected to the device. Body temperature was measured by a rectal thermometer which was a part of the device.

\section{Statistical analysis}

Before significance tests, Numeric data obtained was first evaluated by Shapiro-Wilk test to assess the normality of parametric test assumptions, and Levene test to assess homogeneity of the variances. Variance analysis was used for Dependent quantitative data which were repeated more than two times to test variations. In the case of determined differences, Post-hoc Analysis with Bonferroni correction was used to specify which repetition the differences resulted from. All statistical calculations were analyzed with a minimum of $5 \%$ error margin. Level of significance was determined as $\mathrm{p}<0.05$.

\section{RESULTS}

Changes in systolic and diastolic blood pressure, heart rate per minute and body temperature caused by xylazine-ketamine combination before and after application presented in Table 1 .

Systolic blood pressure was significant at 0,15 and 30 minutes after application in comparison with the measurements at 45, 60 and 120 minutes (Figure 1).

No significant change in diastolic blood pressure (Figure 2). Changes in heart rate were statistically significant $(p<0.001)$. Heart rate measurements showed a significant decrease after the application (at 45, 60 and 120 minutes) in comparison to before application $(\mathrm{p}<0.05)$ (Figure 3$)$.

Body temperature showed a significant fall in comparison to values before application $(\mathrm{p}<0.001)$. Value obtained before application and at 30th minute are statistical meaningful in comparison to values obtained at 45 th, 60th and 120th minutes $(\mathrm{p}<0.05)$ (Figure 4). 
Table 1. Data before and after the xylazine-ketamine combination application.

\begin{tabular}{|c|c|c|c|c|c|c|c|}
\hline \multirow{2}{*}{ Parameter } & \multicolumn{7}{|c|}{ Measurements (minutes) } \\
\hline & 0 & 15 & 30 & 45 & 60 & 120 & $\mathbf{P}$ \\
\hline $\begin{array}{l}\text { Systolic Blood } \\
\text { Pressure }(\mathrm{mmHg})\end{array}$ & $167.417 \pm 4.875^{\mathrm{a}}$ & $169.117 \pm 3.857^{a}$ & $176.233 \pm 6.225^{\mathrm{a}}$ & $158.567 \pm 4.523^{b}$ & $160.167 \pm 3.474^{b}$ & $157.517 \pm 3.711^{\mathrm{b}}$ & 0.010 \\
\hline $\begin{array}{l}\text { Diastolic Blood } \\
\text { Pressure }(\mathrm{mmHg})\end{array}$ & $106.283 \pm 6.413$ & $118.017 \pm 5.189$ & $126.033 \pm 7.839$ & $108.667 \pm 5.835$ & $112.267 \pm 3.971$ & $105.800 \pm 5.995$ & 0.051 \\
\hline Heart rate (bpm) & $90.950 \pm 5.246^{a}$ & $79.783 \pm 5.346^{\mathrm{ab}}$ & $90.633 \pm 4.557^{a}$ & $73.433 \pm 4.199^{b}$ & $69.100 \pm 4.641^{b}$ & $72.767 \pm 3.776^{\mathrm{b}}$ & $<0.001$ \\
\hline Body temp. $\left({ }^{\circ} \mathrm{C}\right)$ & $38.317 \pm 0.121^{\mathrm{a}}$ & $37.710 \pm 0.230^{\mathrm{ab}}$ & $37.925 \pm 0.142^{\mathrm{a}}$ & $37.072 \pm 0.198^{\mathrm{bc}}$ & $37.007 \pm 0.203^{\mathrm{bc}}$ & $36.717 \pm 0.187^{c}$ & $<0.001$ \\
\hline
\end{tabular}

${ }^{*} a, b, c$ : The difference between the groups is statistically significant shown with different letters in the same row $(p<0.05)$.

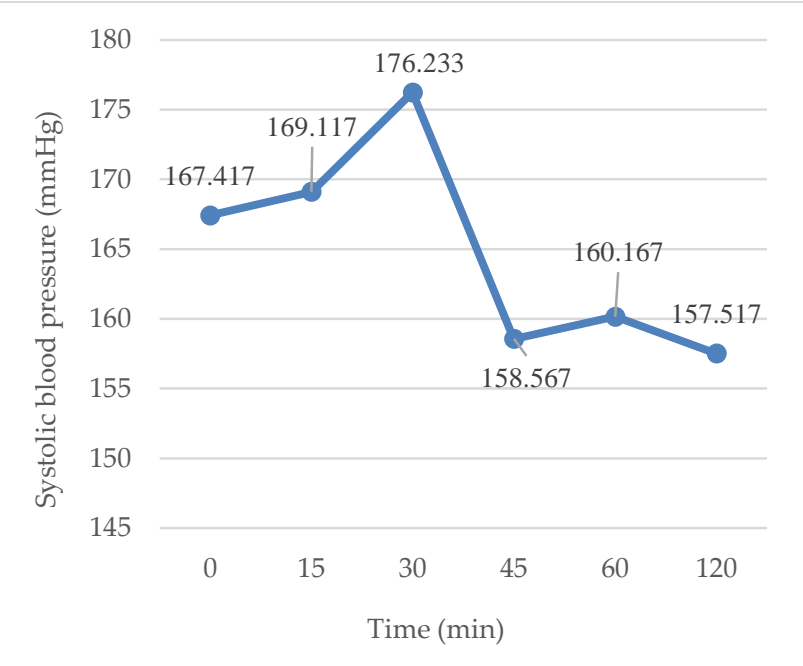

Figure 1. Changes in systolic blood pressure

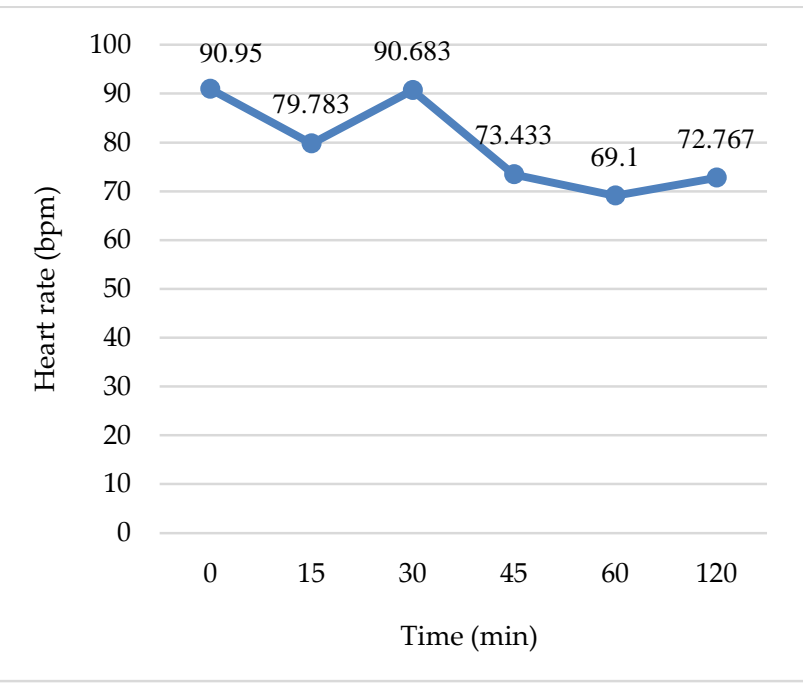

Figure 3. Changes in heart rate

\section{DISCUSSION}

Physiological changes occur due to the effects of anesthetic medications in animals' system. In this study aimed at observing the effects of the

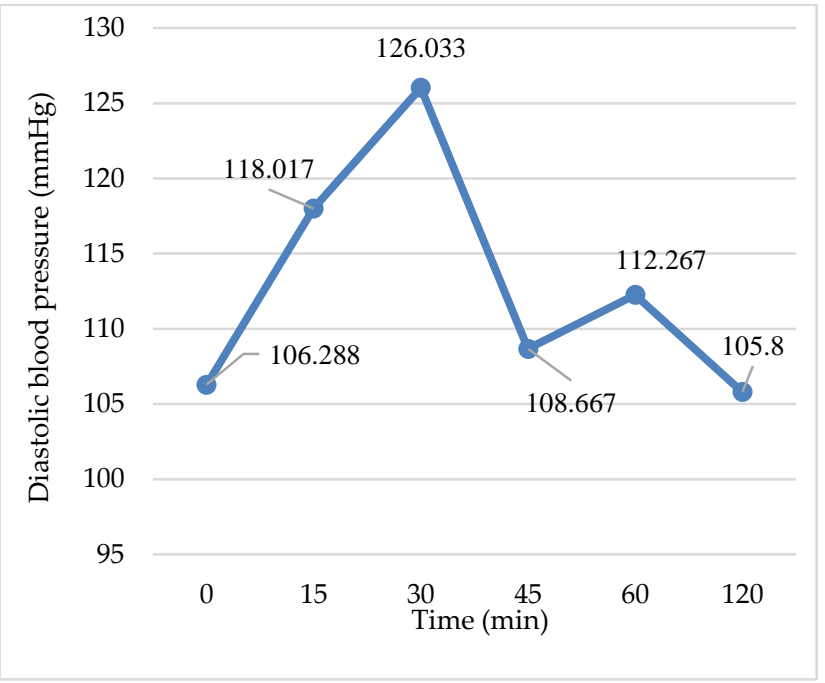

Figure 2. Changes in diastolic blood pressure

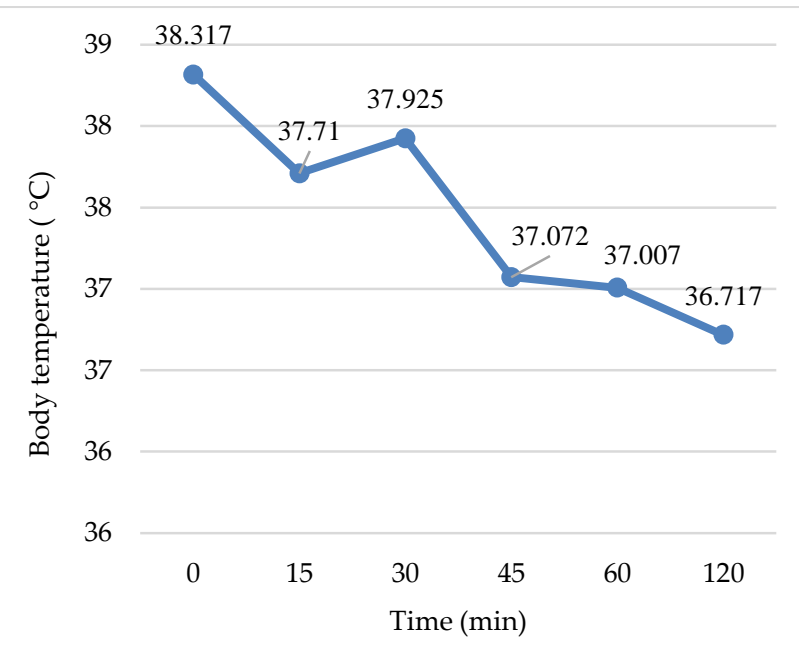

Figure 4. Changes in body temperature due to time

combination of xylazine- ketamine and determining any potential results of blood pressure on dogs.

Xylazine, causes temporary hypertension in arterial blood pressure (Samy and Othman, 1985; Börkü et al., 2005). Ketamine causes rises in blood pressure and heart rate because of stimulating 
cardiovascular system (Colby and Stanford, 1981; Haskins et al., 1985; Izci et al., 1993). Therefore, in our study it is thought that rise in the blood pressure during 15th and 30th minutes cause xylazine to cause temporary hypertension and ketamine stimulating cardiovascular system. In a study conducted by Koç et al., (2002), blood pressure was found to decrease time-dependently, and this decrease indicated that the depressive effect of xylazine in the cardiovascular system was greater than the stimulatory effect of ketamine. Data acquired from our study, drop in arterial blood pressure after 30th minute and reaching out to the minimum value at 120th minute, showed us that our study is compatible with Koç et al., (2002). During our study, significant decrease in heart rate at 60th minute supported literature information about xylazine's depressive effect on cardiovascular system causes a decrease in heart rate (Haskins et al., 1985; Samy and Othman, 1985; Allen et al., 1986; Izci et al., 1993; Koç et al., 2002). Between 15- and 30minutes rise in heart rate was recorded which showed that the idea of ketamine, rising heart rate temporarily is compatible with literature which specifies the same thing (Colby and Stanford, 1981; Haskins et al., 1985; Samy and Othman 1985; Izci et al., 1993).

As a result of vasodilatation that is caused by xylazine's depressive effect on peripheral sympathetic system, fall in body temperature is indicated (Samy and Othman, 1985; Koç et al., 2002). It is also indicated that, drops in body temperature is because of thermoregulation center is being depressed because of ketamine being used with depressive effective anesthetics (Short et al., 1993). In this case, body temperature reaching its minimum value at 120 th minute and showing a significant fall when compared to measurements taken between 0 and 30 minutes are all arise from xylazine depressing peripheral sympathetic system and ketamine depressing thermoregulation center. Facts that obtained from this study are compatible with literature information's (Samy and Othman, 1985; Short et al., 1993; Koç et al., 2002).

\section{CONCLUSION}

Consequently, dogs which were put under anesthesia with the combination of xylazineketamine have shown decreases in arterial blood pressure, heart rate and body temperature.

\section{ACKNOWLEDGMENTS}

This study is made for Kırıkkale University Graduate School of Health Sciences postgraduate program, generated from postgraduate thesis.

Conflict of Interests: The authors declared that there is no conflict of interests.

Financial Disclosure: The authors declared that this study has received no financial support.

Author's Contributions: The study was designed by BO and SG. Measurements were recorded by BO. $\mathrm{BO}$ and SG participated in the interpretation of the results. The draft and revision of the manuscript were done by $\mathrm{BO}$ and SG.

\section{REFERENCES}

Aantaa R, Scheinin M. Alfa-2-adrenergic agents in anaesthesiology. Acta Anaesthes Scand. 1993; 37:433-448.

Allen DG, Dyson DH, Pascoe PJ, O'grady MR. Evaluation of a xylazine-ketamine hydrochloride combination in the cat. Can J Vet Res. 1986; 50:23-26.

Atasoy S, Karadeniz K. Anestezi. İstanbul: Fatih Ofset; 2003.

Bilgili A, Doğan A. Veteriner hekimlikte xylazine antagonistlerinin klinik kullanılması. Yüzüncü Yıl Üniversitesi Veteriner Fakültesi Dergisi. 1991; 2:1-2.

Booth NH. Intravenous and other parenteral anesthetics. In: Booth NH, Mcdonald E, eds. Veterinary Pharmacotogy and Therapeutics. North Carolina: Iowa State Un Press; 1928. p.239-254.

Börkü MK, Özkanlar YE, Gürkan M, Gazyağcı S, Hanedan B. Xylazine ile sedasyon oluşturulan köpeklerde xylazine antagonisti yohimbine'in etkinliğinin araştırılması. Uludağ Üniversitesi Veteriner Fakültesi Dergisi. 2005; 1-2-3-4:27-32.

Cardoso CG, Marques DRC, Silva THM, Mattos-Junior E. Cardiorespiratory, sedative and antinociceptive effects of dexmedetomidine alone or in combination with methadone, morphine or tramadol in dogs. Vet Anaesth Analg. 2014; 41:636-643.

Colby ED, Sanford TD. Blood pressure and heart and respiratory rates of cats under ketamine/xylazine, ketamine/acepromazine anesthesia. Feline Practice. 1981; 11:19-24.

Flecknell P. Basic principles of anaesthesia. In: Flecknell P, eds. Laboratory Animal Anaesthesia. $4^{\text {th }}$ ed. Boston; 2016. p.1-75.

Franceschelli A, Sens J, Herchick S, Thelen C, Pitychoutis PM. Sex differences in the rapid and the sustained antidepressant like effects of ketamine in stress-naive and "Depressed" mice exposed to chronis mild stress. Neuroscience. 2015; 290:4960.

Greene SA, Thurmon JC. Xylazine review of its pharmacology and use in veterinary medicine. J Vet Pharmacol Therap. 1988; 11:295-313.

Gülanber GE, Baştan A, Taşal İ, Aktaş M, Arıkan N. Köpeklerde midazolam ve ketaminle genel anestezi. İstanbul Üniversitesi Veteriner Fakültesi Dergisi. 2001; 27(2):401-409.

Hall LW, Clark KW, Trim CM. Veterinary anaesthesia. $10^{\text {th }}$ ed. London: WB Saunder's Co; 2001. p.352-353. 
Haskins SC, Farver TB, Pau JD. Ketamine in dogs. Am J Vel Res. 1985; 46:1855-1860.

Hellyer PW. General anesthesia for dogs and cats. Vet Med. 1996; 91:314-325.

İzci C, Eksen $\mathbf{M}$, Kot $\mathbf{Y}$, et al. Köpeklerde rompun-ketalar ve acepromazine-ketalar kombinasyonlarının kardiopulmoner etkileri üzerinde karşılaştırmalı araştırmalar. SÜ Vet Fak Derg. 1993; 9:22-27.

Kellihan HB, Stepien RL, Hassen KM, Smith LJ. Sedative and echocardiographic effects of dexmedetominine combined with butorphanol in healthy dogs. J Vet Cardiol. 2015; 17:282-292.

Koç Y, Kul M, Alkan F, Oğurtan Z. Köpeklerde midazolamketamine ve xylazine-ketamine anestezisinin arteriyel kan basıncı ve kan gazları üzerine etkileri. Vet Bil Derg. 2002; 18(1-2):57-62.

Koç B, Sarıtaş ZK. Veteriner Anesteziyoloji ve Reanimasyon. Malatya: Medipress; 2004.

Lemke KA. Anticholinergics and sedatives. In: Tranquilli WJ Thurmon JC, Grimm KA, eds. Lumb and Jones' Veterinary Anesthesia and Analgesia. $4^{\text {th }}$ ed. Iowa: Blackwell Publishing; 2007. p.203-239.
Mihara T, Kikuchi T, Kamiya Y, Koga M, Uchimoto K, Kurahashi K. Day or night administration of ketamine and pentobarbital differentially affect circadian rhythms of pineal melatonin secretion and locomotor activity in rats. Anesth Analg. 2012; 115:805-813.

Murrell JC, Hellebrekers LJ. Medetomidine and dexmedetomidine: A Review of cardiovascular effects and antinociceptive properties in dogs. Vet Anaesth Analg. 2005; 32:117-127.

Samy MT, Othman GM. Clinical application of ketamine and xylazine for anaesthesia in cats. Vet Med Review. 1985; 1:7279.

Short CE, Paddleford RR, Harvey RC. Induction and maintenance of general anaesthesia in small animal practice. Wien Tierarztl Mschr. 1993; 80:177-187.

Sinclair MD. A review of the physiological effects of A2-agonists related to the clinical use of medetomidine in small animal practice. Can Vet J. 2003; 44:885-897.

Topal A. Veteriner Anestezi. Bursa: Nobel\&Güneş Yayınları; 2005. 